terior a l'esclat de la Guerra Freda, fou un fenomen mundial que, tot i disminuït, ha arribat als nostres dies i és difícil de dir si no és per quedar-se: el futur no és cosa dels historiadors, però quan un fenomen resulta tenir un precedent de més de dues dècades en l'etapa d'entreguerres, en dura més de quatre i es mostra tan reticent a morir, sembla manifestar el seu caràcter estructural, amb independència de quina sigui la valoració que fem de la seva natura.

L'experiència de la LCR i de formacions polítiques similars — si als autors no els ha de molestar l'adjectiu - cal valorar-la en la seva justa mesura; per això calen anàlisis aprofundides, no només des de l'òptica de la història de partit: quina fou la seva contribució a la difusió de nous valors i actituds de l'onada de renovació dels anys seixanta (discursos, pràctiques, espais d'influència); quin fou el seu paper en la formació de quadres d'altres partits i organitzacions - un paper involuntari, naturalment-, en la formació personal de professionals qualificats i d'intellectuals (una bona colla de trajectòries personals serien interessantíssimes), en l'eclosió dels mal anomenats nous moviments socials - l'obra ja anticipa coses sobre els espais feminista, pacifista, etc.-, en l'auge del sorgiment de les anomenades organitzacions no governamentals i, encara, en d'altres fenòmens que fan més comprensible la societat d'entre-segles (Xx a XxI).

Com sempre en aquests casos, restarem atents a l'arribada de noves notícies sobre la qüestió, perquè no dubtem que se’n produiran.

Martí Marín Corbera Universitat Autònoma de Barcelona

\title{
Hablan los escritores en catalán durante las postrimerías del franquismo
}

Robert SALADRIGAS. 2014. Paraules d'escriptor. Monòlegs amb creadors catalans dels setanta. Barcelona: Galàxia Gutenberg/Cercle de Lectors, 295 p.

El monólogo, en la práctica periodística de Robert Saladrigas, era una peculiar versión de la entrevista, género cuyo secreto estriba en conocer la materia, saber escuchar y disolverse, dejándole todo el protagonismo 
al entrevistado. Aquí el monólogo no es tal, aunque al estar elididas las preguntas pudiera dar esa impresión. Estas 42 conversaciones aparecieron publicadas en castellano en la revista Destino, entre 1968 y 1975, pero ahora se nos dan traducidas al catalán, lengua usada en los encuentros, en versión de Josep Alemany. Sin embargo, para los escritores que utilizan el mallorquín supone un doble trasvase, como recuerda el mismo Saladrigas.

Se trata de una de las etapas más fértiles de la revista de Vergés, antes de que se hicieran con ella los bárbaros y acabaran liquidándola, reencarnados en esta ocasión en Jordi Pujol y su agradecido chevalier servant Baltasar Porcel, a quien - por cierto - le debemos una de las mejores frases del libro: «la meva novellística, que és on de debò, de debò, m’hi jugo els calés». Saladrigas contaba entonces 28 años y estaba iniciando su trayectoria como narrador, pues aún no había publicado su primera novela notable, Aquell gust agre de l'estel (1977). La elección tanto de los entrevistados, casi todos ellos escritores de ficción, como de los temas que trataron guardar relación con la actualidad del momento, bien sea por la aparición de un nuevo libro, la concesión de un premio o la anormal situación de la lengua catalana.

Como resulta imposible detenerse en todo lo sustancial, voy a ocuparme solo de alguna de las respuestas que me han llamado la atención. Pero quizás antes habría que distinguir entre los escritores que permanecieron aquí tras la guerra; aquellos que optaron por el exilio y los nuevos nombres. Por otra parte, se singularizan los que utilizaron ambas lenguas, como en el caso de Sebastià Juan Arbó, a quien Saladrigas le da un tirón de orejas por abandonar tras la guerra el catalán como lengua literaria por motivos económicos (p. 195); y los periféricos mallorquines. Por ejemplo, Vidal Alcover se queja de que Barcelona siempre le ha negado el pan y la sal y se refiere a la Escola mallorquina como perfectamente definida; mientras que Francesc Vallverdú defiende la entidad de la poesía de la denominada Escola de Girona. En el mismo sentido, Guillem Frontera se lamenta de la excesiva dependencia mallorquina de Madrid y Barcelona.

Joan Sales, con motivo de la edición completa de Incerta glòria en 1969 ( $1^{\mathrm{a}}$ ed., 1956), defiende para la novela una lengua coloquial, viva, en el mismo sentido que Brossa. Y en esa fecha, Joan Oliver, que ya tiene 71 años y 
acaban de concederle el Premi d'Honor de les Lletres Catalanes, afirma que la juventud actual le parece triste. A Tísner, el pintor realista J.-F. Millet, cuyo Ángelus remedó Dalí, le resulta vacuo; en cambio elogia la perfecta mezcla de realidad y fantasía en Cien años de soledad, novela que más adelante tradujo al catalán. Espriu se muestra sorprendido porque le hayan concedido el prestigioso Premio Montaigne, que otorga la Universidad de Tubinga, e ironiza sobre cómo no faltará en Cataluña quien lo acuse de fascista por aceptar un reconocimiento de la Alemania occidental. También confiesa que su mayor ambición sería escribir una «novella llarga» que se titularía La roda del temps. Un autor completamente distinto, como Víctor Mora, defiende el cuento frente a la novela, sobre todo aquellos relatos que tienen inicio y conclusión, la tradición que va de Chéjov a Hemingway, hoy de nuevo tan de moda. Y se plantea una vez más el problema de la lengua, en este caso de su trilingüismo. Calders, cuyos autores favoritos confiesa que son Chéjov, Oscar Wilde y Bontempelli, se lamenta por el estado del cuento literario, excluido de diarios y revistas, y de la inexistencia de una crítica responsable. Pedrolo, quien pronto se convertiría en el mayor best seller de la historia de la literatura catalana, se quejaba en 1970 de que tenía dificultades para publicar. Y, por cierto, Joaquim Carbó lo consideraba entonces el más profesional y mejor novelista. Cucurull, por su parte, critica que algunos pontífices de las letras catalanas lo hayan ignorado, por lo que confiesa que incluso ha llegado a pensar en el suicidio... Y Clementina Arderiu, cuenta entonces 83 años, define su poesía como «íntima i intuïtiva i, sobretot, molt catalana, perquè ho sóc pels meus vuit o deu costats» (p. 229). Y, por último, Teresa Pàmies y Miquel Ángel Riera nos descubren una primera época como escritores en castellano que yo al menos desconocía.

Saladrigas traza a veces un breve retrato de sus protagonistas, valga como prueba el arranque del texto que le dedica a Brossa, o el comentario sobre el cambio de imagen, la modernización de Candel, quien — por cierto- debería haberse incluido en el volumen dedicado a los escritores en castellano, aunque el interés literario de su obra de ficción sea muy escaso, o la semblanza del poeta Tomás Garcés. Así, por ejemplo, Josep Vallverdú, en una de las conversaciones más singulares del libro, afirma no tener vocación literaria e interesarse solo por los encargos concretos y los premios, y no satisfecho con ello apunta que tanto Barcelona como 
Lérida le producen asco. En fin. Sorprende, a veces, el poco creíble desinterés que dicen sentir por la política, o como ocurre en el caso de MariaAurèlia Capmany, quien afirma no ser una mujer política (p. 217).

Pero el escritor periodista que es entonces Saladrigas también se confiesa, por ejemplo cuando en 1970 nos dice que los dos autores españoles que disfruta más leyendo y releyendo son Cunqueiro y Perucho, infravalorados entonces por haberse decantado por la estética de lo fantástico, cuando seguía imperando el realismo, tanto en la literatura en gallego, como en la escrita en catalán o castellano. Por cierto, en la conversación que mantiene con el autor de Les històries naturals, una de las más sustanciosas del libro, éste niega que su obra ni la de Cunqueiro formen parte de la literatura fantástica, sino más bien de la maravillosa y poética; explica las diferencias entre su literatura y la del autor de Merlin y familia, y confiesa que en el fondo sus libros son una reacción contra la falta de libertad, contra el racionalismo que tiene encadenado al mundo actual, en la misma línea de lo que pensaba Calders por esas fechas. Tampoco deja de ser curioso que en 1970 Perucho diera por zanjada su producción, cuando todavía le quedaban por publicar treinta o cuarenta libros.

El caso es que muchos de estos testimonios destilan, como ha señalado con perspicacia Ponç Puigdevall (El País, 23 oct. 2014), insatisfacción por la situación política y lingüística. No en vano, alguno siente la necesidad de definirse como catalanista (Oliver), católico (Pere Ribot), de derechas (Oller i Rabassa), republicano (Jordi Coca), ateo (Pedrolo), contrario a la gauche divine (Vallverdú), demócrata liberal (Capmany) o políticamente pez (Candel), aunque la respuesta más enrevesada e ininteligible sea la de Benet y Jornet (p. 223). No son entrevistas a fondo, pero han quedado como un testimonio de las obsesiones, inquietudes e ilusiones de los escritores y ensayistas catalanes durante la última etapa del franquismo, en unos años en que los autores se callarían cosas por temor a la censura o a las represalias del régimen, pero en donde por otra parte, no se había instalado entre nosotros todavía el pensamiento literario políticamente correcto. Este libro se complementa con otros dos, hermanos gemelos, en los que Saladrigas conversa con los autores hispanoamericanos (Voces del boom, 2011) y los españoles que escribían en castellano (Rostros escritos. Monólogos con creadores españoles de los setenta, 2014). En suma, tres volúmenes que reúnen testimonios imprescindibles para entender lo que 
fue la literatura catalana, hispanoamericana y española cuando apenas empezaba a vislumbrarse el fin de la dictadura franquista.

Fernando Valls

Universitat Autònoma de Barcelona 